\title{
PERAN POLRI DALAM PENEGAKAN HUKUM TERHADAP PERDAGANGAN BARANG IMPOR ILEGAL DI WILAYAH HUKUM POLRES PELABUHAN TANJUNG PERAK
}

\author{
Tio Tondy \\ tiotondy@yahoo.com \\ Program Studi Magister Kajian Ilmu \\ Kepolisian Sekolah Pasca Sarjana \\ Universitas Airlangga Jln. Airlangga \\ No.4-6 Surabaya
}

\begin{abstract}
Indonesia is a country rich in natural resources. The results of natural resources owned are used to meet domestic needs and are exported overseas. Although Indonesia is rich in natural resources, there are limitations to the field of human resources. Limited human resources, including limitations in producing goods, is one of the driving factors in importing goods from abroad to enter Indonesia. Based on the Minister of Trade Regulation No. 48 of 2015 it is known that imported goods are grouped in: a. free imported goods; b. restricted import goods; and c. prohibited import goods. The limitation of imported goods is not without reason, but is in accordance with the facts found in the field that there has been an illegal trade in imported goods entering the territory of the Republic of Indonesia. Even though the Government itself has set various legal products to protect the implementation of import activities to meet the people's needs. In addition, the fact that free trade tends to result in circulating goods and or services does not necessarily guarantee the security, safety and health of consumers. The rise of illegal trade activities, led to the need for a thesis research entitled "The Role of the National Police in Law Enforcement against Illegal Imported Goods Trade in the Law Area of the Tanjung Perak Harbor Police Station".
\end{abstract}

Keywords: Law, Trade, Illegal

\begin{abstract}
Indonesia merupakan negara yang kaya akan sumber daya alam. Hasil dari sumber daya alam yang dimiliki digunakan untuk mencukupi kebutuhan dalam Negeri dan di eskpor ke luar Negeri. Walaupun Indonesia kaya akan sumber daya alamnya, namun terdapat keterbatasan terhadap bidang sumber daya manusia. Keterbatasan sumber daya manusia yang dimiliki, meliputi keterbatasan dalam memproduksi barang, merupakan salah satu faktor pendorong dalam mengimpor barang dari luar negeri untuk masuk ke Indonesia. Berdasarkan Peraturan Menteri Perdagangan No. 48 Tahun 2015 diketahui bahwa barang impor dikelompokkan dalam : a. barang bebas impor; b. barang dibatasi impor; dan c. barang dilarang impor. Pemberian batasan pada barang barang impor bukan tanpa alasan, namun sesuai dengan fakta yang ditemukan di lapangan bahwa telah terjadi perdagangan barang impor illegal yang masuk ke wilayah Republik Indonesia. Padahal Pemerintah sendiri sudah menetapkan berbagai produk hukum untuk melindungi pelaksanaan kegiatan impor untuk mencukupi kebutuhan rakyat. Selain itu, fakta bahwa perdagangan bebas cenderung mengakibatkan barang dan atau jasa yang beredar belum tentu menjamin keamanan, keselamatan dan kesehatan konsumen. Maraknya kegiatan perdagangan secara illegal, menyebabkan perlunya dilakukan penelitian tesis dengan judul "Peran Polri dalam Penegakkan Hukum terhadap Perdagangan Barang Impor Ilegal di Wilayah Hukum Polres Pelabuhan Tanjung Perak".
\end{abstract}

Kata Kunci: Hukum, Perdagangan, Ilegal 


\section{Pendahuluan}

Indonesia merupakan negara yang kaya akan sumber daya alam. Hasil dari sumber daya alam yang dimiliki digunakan untuk mencukupi kebutuhan dalam Negeri dan di eskpor ke luar Negeri. Walaupun Indonesia kaya akan sumber daya alamnya, namun terdapat keterbatasan terhadap bidang sumber daya manusia. Keterbatasan sumber daya manusia yang dimiliki, meliputi keterbatasan dalam memproduksi barang, merupakan salah satu faktor pendorong dalam mengimpor barang dari luar negeri untuk masuk ke Indonesia. ${ }^{1}$

Impor dapat diartikan sebagai pembelian barang dan jasa dari luar negeri ke dalam negeri dengan perjanjian kerjasama antara dua negara atau lebih. Impor juga bisa dikatakan sebagai perdagangan dengan cara memasukkan barang dari luar negeri ke wilayah Indonesia dengan memenuhi ketentuan yang berlaku. Impor adalah proses transportasi barang atau komoditas dari suatu negara ke negara lain secara legal, umumnya dalam proses perdagangan. ${ }^{2}$

Proses impor umumnya adalah tindakan memasukan barang atau komoditas dari negara lain ke dalam negeri. Impor barang secara besar umumnya membutuhkan campur tangan dari bea cukai di negara pengirim maupun penerima. Impor adalah bagian penting dari perdagangan internasional. Kegiatan impor dilakukan untuk memenuhi kebutuhan rakyat. Produk impor merupakan barang- barang yang tidak dapat dihasilkan atau negara yang sudah dapat dihasilkan, tetapi tidak dapat mencukupi kebutuhan rakyat. ${ }^{3}$

Berdasarkan Peraturan Menteri Perdagangan No. 48 Tahun 2015 perlu diketahui bahwa barang impor dikelompokkan dalam : a. barang bebas impor; b. barang dibatasi impor; dan c. barang dilarang impor. Barang-barang impor yang masuk ke suatu negara sudah merupakan keniscayaan. Hal itu disebabkan karena adanya kemungkinan komoditi yang dibutuhkan tidak semua ada di suatu negara. Walaupun ada, tetapi jumlahnya tidak memadai atau karena adanya faktor-faktor tertentu yang membuat suatu negara melakukan kegiatan impor. ${ }^{4}$ Banyaknya barang luar negeri yang masuk ke Indonesia, sehingga pemerintah memberikan batasan-batasan terhadap barang yang dapat di impor atau diperjualbelikan. ${ }^{5}$

\footnotetext{
1 Jimmy Benny. Ekspor dan Impor Pengaruhnya Terhadap Posisi Cadangan Devisa di Indonesia. Jurnal EMBA Vol. 1 No. 4 Desember, 2013.

2 Ibid

${ }^{3} \mathrm{lbid}$
} 
${ }^{4}$ Rina Oktaviani. Laporan Akhir Pengkajian Hukum Tentang Penegakkan Hukum Pemberantasan Mafia Impor Pangan. Kementerian Hukum dan Hak Asasi Manusia RI, Jakarta, 2015.

5 Aan Haryono. Arus Ekspor dan Impor Meningkat di Pelabuhan Tanjung Perak. https://ekbis.sindonews.com/read/1219331/34/arus-ekspor-dan-impor-meningkat-di-pelabuhan-tanjungperak-1499676140. Diakses 7 April 2018.

Pemberian batasan tersebut bukan tanpa alasan, namun sesuai dengan fakta yang ditemukan di lapangan bahwa telah terjadi perdagangan barang impor illegal yang masuk ke wilayah Republik Indonesia. Padahal Pemerintah sendiri sudah menetapkan berbagai produk hukum untuk melindungi pelaksanaan kegiatan impor untuk mencukupi kebutuhan rakyat. ${ }^{6}$ Produk-produk illegal tersebut dapat berupa seperti mainan anak, keramik, pakaian bekas, elektronik bekas, rokok produk luar negeri yang tidak dilekati pita cukai Indonesia, minuman keras (minuman yang mengandung etil alkohol) dan produk- produk lainnya. Hal ini dilakukan untuk mendapatkan keuntungan yang besar. Kondisi demikian yang akhirnya membuat perdagangan di Indonesia semakin perlu diawasi. ${ }^{7}$

Kemampuan penegakkan hukum di atas, tentunya harus sesuai dengan perundang-undangan yang berlaku. Dalam Undang-Undang Nomor 7 Tahun 2014 tentang Perdagangan (UU Perdagangan) dijelaskan bahwa perdagangan adalah tatanan kegiatan yang terkait dengan transaksi Barang dan/atau Jasa di dalam negeri dan melampaui batas wilayah negara dengan tujuan pengalihan hak atas Barang dan/atau Jasa untuk memperoleh imbalan atau kompensasi. Ancaman pidana bagi pelaku apabila dilakukan pelanggaran baik perdagangan dalam negeri maupun luar negeri. Salah satu bunyi pasal yang mana menyebutkan sanksi pidana bagi perdagangan luar negeri khusunya importir yaitu berbunyi pelaku dipenjara paling lama lima tahun dan atau pidana denda paling banyak lima miliar rupiah bagi pelaku usaha yang memperdagangkan barang di dalam negeri yang tidak memenuhi SNI yang diberlakukan secara wajib atau persyaratan teknis yang telah diberlakukan secara wajib diatur dalam Pasal 113. Walaupun pengawasan telah dilakukan oleh pejabat yang berwenang tetapi masih ada kegiatan penyelundupan yang dilakukan di wilayah Republik Indonesia.

Selain itu, fakta bahwa perdagangan bebas cenderung mengakibatkan barang dan atau jasa yang beredar belum tentu menjamin keamanan, keselamatan dan kesehatan konsumen. Lebih-lebih keadaan konsumen yang rata-rata kurang bersikap hati-hati, kondisi tersebut dikarenakan posisi pihak konsumen berada dipihak lemah dalam menghadapi pihak produsen. Oleh karena timbulnya permasalahan tersebut, pemerintah mengeluarkan suatu produk hukum yaitu Undang-Undang Nomor 8 Tahun 
${ }^{6}$ Jimmy Benny, Loc. Cit.

7 Ibid. 
1999 tentang Perlindungan Konsumen. Untuk melindungi hak-hak konsumen, hak atas kenyamanan, keamanan, dan keselamatan dalam mengkonsumsi barang dan/atau jasa. Dengan adanya undang-undang tersebut diharapkan dapat menjamin tercapainya penyelenggaraan perlindungan konsumen di masyarakat.

Beberapa kasus yang ditemukan di lapangan yaitu semisal pada tahun 2016, dimana ditemukan perdagangan jenis barang impor tandon, sebanyak 2 (dua) unit. Barang ini diduga merupakan barang tanpa dilengkapi dengan label bahasa Indonesia, SNI dan merek, sebagaimana dimaksud dalam Pasal 104, Pasal 113 UU No. 7 Tahun 2014 tentang Perdagangan dan atau Pasal 120 UU No. 3 Tahun 2014 tentang Perindustrian dan atau Pasal 62 UU No. 8 Tahun 1999 tentang Perlindungan Konsumen.

Pada tahun 2017 sendiri, telah ditemukan penjualan barang impor dengan jenis speaker sebanyak 20 unit, dimana pelaku usaha telah melanggar ketentuan tidak memiliki sertiifkat atau penyelenggara telekomunikasi. Hal ini tentu saja melanggar Pasal 62 ayat (1) jo. Pasal 8 ayat (1) huruf "a" UU No. 8 tahun 1999 tentang Perlindungan Konsumen Jo. Pasal 22 Jo. Pasal 2 Peraturan Menteri Perhubungan No. KM. 10 tahun 2005 tentang sertifikasi alat dan perangkat telekomunikasi dan atau Pasal 47 jo. Pasal 11 ayat (1) UU No. 36 Tahun 1999 tentang Telekomunikasi jo. Pasal 39 Permen Kominfo Nomor: 29/PER/ M.KOMINFO/09/2008 tentang Sertifikasi Alat dan Perangkat Telekomunikasi, dimana berbunyi pelaku usaha dilarang memproduksi dan atau memperdagangkan barang dan atau jasa yang tidak memenuhi atau tidak sesuai standar yang dipersyaratkan dan ketentuan peraturan perundang-undangan Jo. Setiap alat dan perangkat telekomunikasi yang dibuat, dirakit, dimasukkan untuk diperdagangkan dan atau digunakan di wilayah Negara Republik Indonesia wajib melalui sertifikasi dan atau Penyelenggara Telekomunikasi dapat diselenggarakan setelah mendapat izin dari Menteri.

Maraknya kegiatan perdagangan secara ilegal seperti yang digambarkan di atas, yang menyebabkan perlunya dilakukan penelitian tesis dengan judul "Peran Polri dalam Penegakkan hukum terhadap perdagangan barang impor ilegal di wilayah hukum Polres Pelabuhan Tanjung Perak”.

\section{Metode}


Tipe penelitian yang akan digunakan dalam Penelitian tesis ini adalah penelitian sosiologi hukum atau sosio legal, karena penelitian ini terfokus pada gejala sosial dan hukum dalam masyarakat. Penelitian hukum yang sosiologis dilakukan untuk mengamati berlakunya suatu hukum dalam pergaulan antara individu. Hal ini terkait dengan penegakkan hukum pelanggaran di bidang perdagangan barang impor illegal di masyarakat Surabaya, khususnya di wilayah hukum Polres Pelabuhan Tanjung Perak.

\section{Pembahasan}

\section{Gambaran Umum Kepolisian Resort Tanjung Perak}

Kepolisian Resort (Polres) Tanjung Perak yang terletak di Jalan Kalianget No. 1 Perak Utara Pabean Cantikan Kota Surabaya Jawa Timur 60165, dipimpin oleh AKBP Antonius Agus Rahmanto, S.I.K, Msi. wilayah Tanjung Perak berada di posisi geografis antara $7^{\circ} 11^{1} \quad 59,14^{11}$ LS dan $112^{\circ} 4^{1}$ 02,4411 BT. Wilayah Polres Pelabuhan Tanjung Perak Surabaya merupakan daerah Lalu lintas perekonomian yang memiliki Pelabuhan Penumpang dan Barang baik antar Pulau maupun Eksport/Import, tempat-tempat/lapangan terbuka untuk menimbun/ menumpuk barang, Gudang, Pelabuhan TPS serta Obyek Vital.

\section{Dasar Kewenangan Polri dalam Bidang Kepabeanan}

Berikut adalah beberapa dasar atau aturan yang di dalamnya mengatur mengenai kewenangan Polri dalam bidang kepabeanan, termasuk untuk Polres Tanjung Perak:

1. Pasal 59 (1) Undang-Undang Republik Indonesia Nomor 8 Tahun 1999 tentang Perlindungan Konsumen.

2. Pasal 112 (1) Undang-Undang Nomor 10 Tahun 1995 tentang Kepabeanan.

3. Pasal 76 (1) dan (2) Undang-Undang Nomor 17 Tahun 2006 tentang Perubahan atas Undang- Undang Nomor 10 Tahun 1995 tentang Kepabeanan.

4. Pasal 103 (4) Undang-Undang Nomor 7 tahun 2014 tentang Perdagangan.

5. Peraturan Pemerintah Nomor 55 Tahun 1996 tentang penyidikan tindak pidana dibidang Kepabeanan dan Cukai. 
6. Peraturan Kapolri Nomor 20 tahun 2010 tentang Koordinasi, Pengawasan dan Pembinaan Penyidikan bagi PPNS.

7. JUKNIS tahun 2002 tentang Mekanisme Koordinasi dan Pengawasan Penyidik Pegawai Negeri Sipil serta

8. JUKLAK tahun 2002 tentang Hubungan Kerja antara Penyidik POLRI dengan Penyidik Pegawai Negeri Sipil.

\section{Kewenangan Penyidik Polri dalam Melakukan Penyidikan Tindak Pidana dibidang Impor}

\section{Ilegal}

Apabila melihat ketentuan yang ada dalam Undang-undang Nomor 10 Tahun 1995 tentang Kepabeanan, belum ada rumusan pengaturan yang jelas tentang bagaimana kedudukan dan kewenangan penyidik Kepolisian Negara Republik Indonesia (POLRI) yang merupakan penyidik umum sebagamana diatur dalam Undang-undang nomor 8 Tahun 1981 tentang Hukum Acara Pidana. Namun dalam Undang-Undang Nomor 17 Tahun 2006 tentang Perubahan atas Undang- Undang Nomor 10 Tahun 1995 tentang Kepabeanan, pada Pasal 76 ayat (1) dan ayat (2) dijelaskan secara eksplisit bahwa:

(1) Dalam melaksanakan tugas berdasarkan Undang-Undang ini pejabat bea dan cukai dapat meminta bantuan Kepolisian Republik Indonesia, Tentara Nasional Indonesia, dan/atau instansi lainnya.

(2) Atas permintaan sebagaimana dimaksud pada ayat (1), Kepolisian Republik Indonesia, Tentara Nasional Indonesia, dan/atau instansi lainnya berkewajiban untuk memenuhinya. Pada Bab Penyidikan Pasal 112 ayat (1) Undang-Undang Nomor 10 Tahun 1995 tentang Kepabeanan, juga menyebutkan:

(1) Pejabat Pegawai Negeri Sipil tertentu di lingkungan Direktorat Jenderal Bea dan Cukai diberi wewenang khusus sebagai penyidik sebagaimana dimaksud dalam Undang-undang Nomor 8 Tahun 1981 tentang Hukum Acara Pidana untuk melakukan penyidikan tindak pidana di bidang Kepabeanan. 
Hal ini berarti, Polri tidak bertugas pada bidang penyidikan dalam kepabeanan, kecuali dibutuhkan oleh pihak Bea dan Cukai, karena penyidik pada Kepabeanan juga dilakukan oleh Pejabat Pegawai Negeri Sipil (PPNS). Pengaturan yang lebih jelas menyatakan bagaimana kedudukan dan kewenangan penyidik Kepolisian Negara Republik Indonesia dalam penyidikan pelanggaran perdagangan barang impor ilegal, terdapat dalam Peraturan Pemerintah Nomor 55 Tahun 1996 tentang penyidikan tindak pidana di bidang Kepabeanan dan Cukai. Dalam Peraturan Pemerintah tersebut mengatur bahwa dalam situasi tertentu, penyidikan terhadap tindak pidana di bidang Kepabenan dan Cukai dapat dilakukan oleh penyidik Kepolisian Negara Republik Indonesia.

\section{Kedudukan Penyidik Polri terhadap Penyidik Pegawai Negeri Sipil (PPNS) Direktorat Jenderal Bea dan Cukai}

Secara umum penyidik Kepolisian Negara Republik Indonesia (POLRI) berkedudukan sebagai pihak yang mengkoordinasi dan mengawasi opersional seluruh Penyidik Pegawai Negeri Sipil (PPNS) yang berada di lingkungan instansi pemerintah manapun, yang oleh undang-undang diberikan kewenangan untuk menjadi penyidik terhadap suatu tindak pidana yang diatur dalam undang-undang.

Dalam struktur organisasi Kepolisian Negara Republik Indonesia (POLRI), fungsi tersebut secara lebih khusus dijalankan oleh seksi koordinasi dan pengawasan Penyidik Pegawai Negeri Sipil (Siskorwas PPNS) yang berada di bawah lingkup kekuasaan Direktorat Reserse Kriminal Khusus (Ditreskrimsus), yang terdapat dimasing-masing kepolisian Negara Republik Indonesia tingkat Daerah (POLDA). Dalam proses penyidikan tindak pidana dibidang impor ilegal atau kepabeanan, penyidik Kepolisian Negera Republik Indonesia (POLRI) juga berkedudukan sebagai pihak yang mengkoordinasi.

Berdasarkan UU Kepolisian, Penyidik Pegawai Negeri Sipil adalah salah satu pengemban fungsi kepolisian yang membantu Kepolisian Negara Republik Indonesia dan melaksanakan kewenangan berdasarkan Undang Undang masing-masing. PPNS Menjalankan penyidikan berdasarkan KUHAP tetapi berdasarkan kewenangan yang diberikan undang undang spesifik masing-masing. Peraturan Kapolri No. 6 Tahun 2010 tentang Manajemen Penyidikan Penyidik Pegawai Negeri Sipil (PPNS). PPNS bukan merupakan subordinasi dari lembaga Kepolisian yang merupakan bagian dari 
Sistem Peradilan Pidana (Criminal Justice System), akan tetapi PPNS di luar subsistem peradilan tidak boleh mengacaukan sistem peradilan pidana yang telah ada.

\section{Barang Impor Ilegal di Wilayah Hukum Polres Tanjung Perak}

Menurut UU Perdagangan, Perdagangan adalah tatanan kegiatan yang terkait dengan transaksi Barang dan/atau Jasa di dalam negeri dan melampaui batas wilayah negara dengan tujuan pengalihan hak atas Barang dan/atau Jasa untuk memperoleh imbalan atau kompensasi. Tujuan pengaturan kegiatan perdagangan adalah:

1. Meningkatkan pertumbuhan ekonomi nasional;

2. Meningkatkan penggunaan dan perdagangan produk dalam negeri;

3. Meningkatkan kesempatan berusaha dan menciptakan lapangan pekerjaan;

4. Menjamin kelancaran distribusi dan ketersediaan barang kebutuhan pokok dan barang penting;

5. Meningkatkan fasilitas, sarana, dan prasarana perdagangan;

6. Meningkatkan kemitraan antara usaha besar dan koperasi, usaha mikro, kecil, dan menengah, serta pemerintah dan swasta;

7. Meningkatkan daya saing produk dan usaha nasional;

8. Meningkatkan citra produk dalam negeri, akses pasar, dan ekspor nasional;

9. Meningkatkan perdagangan produk berbasis ekonomi kreatif;

10. Meningkatkan pelindungan konsumen;

11. Meningkatkan penggunaan SNI;

12. Meningkatkan pelindungan sumber daya alam; dan

13. Meningkatkan pengawasan barang dan/atau jasa yang diperdagangkan.

Makna barang impor ilegal adalah barang-barang yang didatangkan dari luar negeri secara illegal tanpa dilengkapi dokumen kepabeanan. Barang-barang tersebut biasanya diperoleh dengan cara menyelundupkan dari luar negeri ke dalam daerah pabeanan. Undang-undang yang mengatur penyelundupan terkait masuknya barang impor secara ilegal ini adalah Undang-Undang Nomor 10 Tahun 1995 jo. UndangUndang Nomor 17 Tahun 2006 tentang Kepabeanan.

Pengamat Ekonomi, Chatib Basri, bersama Lembaga Penyelidikan Ekonomi Masyarakat Universitas Indonesia (LPEMUI) telah melakukan penelitian ihwal penyelundupan yang terjadi di Indonesia, mulai dari dampak, akibat, penyebab, hingga solusinya. Chatib menyimpulkan bahwa penyelundupan bisa terjadi akibat tiga 
hal yang saling berkaitan, yaitu kegagalan sistem bea dan cukai, aparat yang korup, serta kebijakan pemerintah yang menuntun pada terciptanya perbedaan harga barang domestik dengan harga di luar negeri. ${ }^{8}$

Sebagai salah satu pelabuhan internasional di Indonesia, masalah yang ditemui di Pelabuhan Tanjung Perak adalah masalah terkait dengan manifest, terdapat komoditi barang impor ilegal yang melanggar peraturan yang telah ditetapkan. Adapun jika dilihat dari jenis komoditi yang diduga sebagai barang impor ilegal yaitu sebagai berikut:

8 Donny Eriyanto, Penyelundupan Lebih Berbahaya daripada Tsunami, Warta Bea Cukai. Edisi 370 September 2005 
Tabel 1.1 Komoditas Barang Impor Ilegal yang ditangani Polres Tanjung Perak

\begin{tabular}{|c|l|c|}
\hline No. & $\begin{array}{l}\text { Jenis } \\
\text { Komoditi }\end{array}$ & \multicolumn{1}{c|}{ Keterangan } \\
\hline 1 & Mainan anak & Sepeda anak, motor cycle \\
\hline 2 & Keramik & - \\
\hline 3 & Tandon & $\begin{array}{c}\text { Speaker aktif, speaker bluetooth dan } \\
\text { speaker portable. }\end{array}$ \\
\hline 4 & Speaker & \\
\hline
\end{tabular}

Sumber: Data Polres Tanjung Perak, 2018

Dari tabel di atas, dapat dilihat bahwa barang impor ilegal yang masuk di wilayah hukum Polres Tanjung Perak yaitu berupa mainan anak (sepeda anak dan motor cycle), keramik, tandon dan speaker (Speaker aktif, speaker bluetooth dan speaker portable). Adapun barang-barang tersebut diimpor masuk ke Indonesia tanpa dilengkapi label SNI, tanpa dilengkapi bahasa Indonesia dan sejumlah peraturan lainnya. Meskipun telah diketahui tidak terdapat label SNI, namun faktanya barangbarang tersebut berhasil diperjualbelikan di pasar Surabaya atau Jawa Timur melalui pelabuhan Tanjung Perak.

Hal ini tentu saja menyalahi aturan jual beli yang telah diatur dalam UndangUndang Nomor 7 Tahun 2014 tentang Perdagangan dan Undang-Undang Nomor 8 Tahun 1999 tentang Perlindungan Konsumen yang berlaku. Oleh karena itu perlu tindakan dari Polri yakni Polres Tanjung Perak, karena sejatinya kegiatan perdangan barang impor ilegal ini dapat berpotensi menganggu keamanan masayarakat. Suatu produk yang diperjualbelikan oleh pelaku usaha menurut UU Perlindungan Konsumen, menyatakan bahwa pelaku usaha menjamin mutu barang dan/atau jasa yang diproduksi dan/atau diperdagangkan berdasarkan ketentuan standar mutu barang dan/atau jasa yang berlaku.

Apabila dianalisis beberapa ketentuan yang mengatur perbuatan yang dilarang dalam UU Perdagangan cukup banyak. Larangan berkaitan dengan pelanggaran kewajiban yang ditetapkan diantaranya: Barang yang diperdagangkan di Indonesia harus memenuhi standar SNI dan menggunakan label berbahasa Indonesia, kewajiban untuk memiliki izin di bidang perdagangan, larangan untuk pedagang distribusi barang menggunakan skema piramida, larangan melakukan penimbunan barang, larangan memperdagangkan barang barang yang ditetapkan sebagai barang yang dilarang. Adapun tujuan pembentukan UU Perdagangan antara lain adalah untuk 
melindungi kedaulatan ekonomi, perlindungan dan pengamanan perdagangan, mengendalikan barang kebutuhan pokok dan barang penting. 
Koordinasi antar penegak hukum memegang peranan penting dalam proses penegakan hukum terhadap tindak pidana penyelundupan barang impor, pada proses penyidikan tidak hanya melibatkan POLRI sebagai penyidik tetapi juga melibatkan Penyidik Pegawai Negeri Sipil (PPNS) dari berbagai instansi yang diberi kewenangan oleh undang undang.

Pada dasarnya, UU Perlindungan Konsumen mewajibkan pelaku usaha (termasuk importir) yang akan memperdagangkan barang-barang di Indonesia mencantum-kan informasi dan/atau petunjuk penggunaan barang dalam Bahasa Indonesia. Akan tetapi, untuk beberapa barang impor yang masuk di Polres Tanjung Perak tidak mencantumkan bahasa Indonesia di buku manual, sehingga dianggap membahayakan dalam penggunaannya, kecuali apabila barang tersebut tidak termasuk barang yang wajib dilengkapi dengan petunjuk penggunaan berdasarkan Permendag

19/2009.

Meski demikian, karena dalam UU Perlindungan Konsumen mewajibkan pelaku usaha untuk mencantumkan informasi dan/atau petunjuk penggunaan barang dalam bahasa Indonesia, maka disarankan agar importir tetap mencantumkan informasi dan/atau petunjuk penggunaan baterai atau senter tersebut.

Bagi produk elektronika dan telematika, produk-produk yang diwajibkan menggunakan petunjuk penggunaan (manual) berbahasa Indonesia yang diatur dalam Peraturan Menteri Perdagangan Nomor 19/M-DAG/PER/5/2009 tentang Pendaftaran Petunjuk Penggunaan (Manual) dan Kartu Jaminan/ Garansi Purna Jual dalam Bahasa Indonesia Bagi Produk Telematika dan Elektronika.

Menurut Permendag Nomor 19 Tahun 2009 tersebut diatur bahwa setiap produk telematika dan elektronika yang diproduksi dan/atau diimpor untuk diperdagangkan di pasar dalam negeri wajib dilengkapi dengan petunjuk penggunaan dan kartu jaminan dalam Bahasa Indonesia. Mengenai produk telematika dan elektronika apa saja yang harus dilengkapi dengan manual berbahasa Indonesia, dapat dilihat dalam Lampiran I Permendag 19/2009 tersebut.

\section{Peran Polri dalam Penindakan Pelanggaran Perdagangan Barang Impor Ilegal}

Proses penegakkan hukum di Indonesia, diawali dengan penanganan kasus-kasus di tingkat penyidikan di kepolisian. Sehingga penting untuk dijabarkan tugas dan 
kepolisian sebagai subsistem dalam penegakkan hukum. Undang-Undang Nomor 2 Tahun 2002 Pasal 1 ayat (1) tentang Kepolisian Negara Republik Indonesia menyebutkan bahwa Kepolisian adalah segala hal- ihwal yang berkaitan dengan fungsi dan lembaga polisi sesuai dengan peraturan perundang- undangan. Jadi kepolisian menyangkut semua aspek yang berkaitan dengan tugas dan wewenang kepolisian serta kelembagaan yang ada di dalamnya. Tugas pokok Kepolisian dalam Undang-Undang Nomor 2 Tahun 2002 tentang Kepolisian Negara Republik Indonesia, dijelaskan pada Pasal 13, bahwa tugas pokok Kepolisian Negara Republik Indonesia adalah: a. Memelihara keamanan dan ketertiban masyarakat; b. Menegakkan hukum; dan c. Memberikan perlindungan, pengayoman, dan pelayanan kepada masyarakat. Berdasarkan ketiga tugas pokok kepolisian yang dijelaskan pada Pasal 14 bahwa dalam melaksanakan tugas pokok sebagaimana dimaksud dalam Pasal 13, Kepolisian Negara Republik Indonesia bertugas:

a. Melaksanakan pengaturan, penjagaan, pengawalan, dan patroli terhadap kegiatan masyarakat dan pemerintah sesuai kebutuhan;

b. Menyelenggarakan segala kegiatan dalam menjamin keamanan, ketertiban, dan kelancaran lalu lintas di jalan;

c. Membina masyarakat untuk meningkatkan partisipasi masyarakat, kesadaran hokum masyarakat serta ketaatan warga masyarakat terhadap hukum dan peraturan perundang- undangan;

d. Turut serta dalam pembinaan hukum nasional;

e. Memelihara ketertiban dan menjamin keamanan umum;

f. Melakukan koordinasi, pengawasan, dan pembinaan teknis terhadap kepolisian khusus, penyidik pegawai negeri sipil, dan bentuk-bentuk pengamanan swakarsa;

g. Melakukan penyelidikan dan penyidikan terhadap semua tindak pidana sesuai dengan hokum acara pidana dan peraturan perundang-undangan lainnya;

h. Menyelenggarakan identifikasi kepolisian, kedokteran kepolisian, laboratorium forensik dan psikologi kepolisian untuk kepentingan tugas kepolisian;

i. Melindungi keselamatan jiwa raga, harta benda, masyarakat, dan lingkungan hidup dari gangguan ketertiban dan/atau bencana termasuk memberikan bantuan dan pertolongan dengan menjunjung tinggi hak asasi manusia;

j. Melayani kepentingan warga masyarakat untuk sementara sebelum ditangani oleh instansi dan/atau pihak yang berwenang; 
k. Memberikan pelayanan kepada masyarakat sesuai dengan kepentingannya dalam lingkup tugas kepolisian; serta

1. Melaksanakan tugas lain sesuai dengan peraturan perundangundangan.

Wewenang kepolisian dalam Pasal 15 ayat (1) dalam Undang-Undang Nomor 2 Tahun 2002 tentang Kepolisian Negara Republik Indonesia disebutkan bahwa:

a. Menerima laporan dan/atau pengaduan;

b. Membantu menyelesaikan perselisihan warga masyarakat yang dapat mengganggu ketertiban umum;

c. Mencegah dan menanggulangi tumbuhnya penyakit masyarakat;

d. Mengawasi aliran yang dapat menimbulkan perpecahan atau mengancam persatuan dan kesatuan bangsa;

e. Mengeluarkan peraturan kepolisian dalam lingkup kewenangan administratif kepolisian;

f. Melaksanakan pemeriksaan khusus sebagai bagian dari tindakan kepolisian dalam rangka pencegahan;

g. Melakukan tindakan pertama di tempat kejadian;

h. Mengambil sidik jari dan identitas lainnya serta memotret seseorang;

i. Mencari keterangan dan barang bukti;

j. Menyelenggarakan Pusat Informasi Kriminal Nasional;

k. Mengeluarkan surat izin dan/atau surat keterangan yang diperlukan dalam rangka pelayanan masyarakat;

1. Memberikan bantuan pengamanan dalam sidang dan pelaksanaan putusan pengadilan, kegiatan instansi lain, serta kegiatan masyarakat;

m. Menerima dan menyimpan barang temuan untuk sementara waktu.

Penegakkan hukum adalah suatu usaha untuk menanggulangi kejahatan secara rasional, memenuhi rasa keadilan dan berdaya guna. Dalam rangka menanggulangi kejahatan terhadap berbagai sarana sebagai reaksi yang dapat diberikan kepada pelaku kejahatan, berupa sarana pidana maupun non hukum pidana, yang dapat diintegrasikan satu dengan yang lainnya. Apabila sarana pidana dipanggil untuk menanggulangi kejahatan, berarti akan dilaksanakan politik hukum pidana, yakni mengadakan 
pemilihan untuk mencapai hasil perundang-undangan pidana yang sesuai dengan keadaan dan situasi pada suatu waktu dan untuk masa-masa yang akan datang. ${ }^{9}$

Dalam kaitannya dengan penindakan terhadap kasus-kasus pelanggaran perdagangan barang impor illegal, tugas Polri selaku penyelidik dan penyidik adalah sebagai berikut:

${ }^{9}$ Barda Nawawi Arief. Kebijakan Hukum Pidana.Citra Aditya Bakti, Bandung, 2002, h. 11. 
1. Mencari Informasi Adanya Barang Impor Ilegal

Beredarnya produk-produk luar negeri di pasaran domestik yang merupakan produk yang terkena ketentuan larangan dan pembatasan, seperti pakaian bekas, elektronik bekas, rokok produk luar negeri yang tidak dilekati pita cukai Indonesia, minuman keras minuman mengandung etil alkohol (MMEA) dan produk-produk lainnya, membuktikan bahwa masih terdapat praktik pemasukan barang impor secara ilegal yang tidak memenuhi ketentuan dalam peraturan perundangundangan bidang kepabeanan ke dalam wilayah Republik Indonesia.

2. Melakukan Penyelidikan ke Tempat Penyimpanan Barang Impor

Salah satu tugas yang dibebankan kepada kepolisian adalah penanganan permasalahan ekspor impor termasuk potensi penyeludupan barang impor ilegal. Kepolisian dituntut untuk menjaga dan meindungi hak masyarakat dalam hal barang dan jasa.

3. Melakukan Koordinasi dengan Bea dan Cukai Terkait Izin Impor Barang

Koordinasi adalah bagian dari kerjasama berbagai pihak untuk melakukan penjagaan dan pemantauan serta penanganan mengenai masalah tindak pidana barang impor ilegal. Koordinasi ini dimaksudkan untuk memaksimalkan setiap pengawasan dan pemantauan kegiatan yang terjadi di Pelabuhan Tanjung Perak.

4. Melakukan Penyitaan Barang Impor yang Ilegal dan Lab Sampel Barang Impor

Barang bukti adalah suatu objek yang menjadi salah satu syarat wajib terjadinya pidana. Penyitaan barang impor yang ilegal dan dianalisis dalam lab sebagai sampel wajib terjadinya pidana sangat dibutuhkan, karena setiap kejadian yang dianggap tidak sesuai dengan undang- undang atau tata tertib harus dilengkapi oleh barang bukti, yang mana menjadi objek sangat penting sebagai syarat sah pidana.

\section{Kesimpulan}


Peran Polri dalam penegakkan hukum terhadap pelanggaran perdagangan barang impor ilegal yang terjadi di wilayah hukum Polres Pelabuhan Tanjung Perak adalah dengan mencari informasi adanya barang impor illegal, melakukan penyelidikan ke tempat penyimpanan barang impor, melakukan koordinasi dengan penyidik PNS di bidang Kepabeanan bea dan cukai terkait izin barang impor, serta melakukan penyitaan barang impor yang ilegal dan lab sampel barang impor.

Kendala yang dihadapi dalam penegakkan hukum perdagangan barang impor ilegal yang terjadi di wilayah hukum Polres Pelabuhan Tanjung Perak yaitu kendala internal dan eksternal. Kendala internal terkait dengan kurangnya pengetahuan anggota terkait pemeriksaan izin-izin legalitas perusahaan maupun dokumen impor, kurangnya pengetahuan anggota terkait akses pengak hukum dalam prosedur barang impor, serta kerjasama antara Polres Pelanbuhan Tanjung Perak dengan pihak lainnya kurang optimal. Sementara itu, kendala eksternal terkait dengan konsumen yang tidak melapor, importir lebih memilih barang dengan harga beli murah, serta minimnya sosialisasi hukum bagi importir dan konsumen mengenai barang impor ilegal.

Upaya mengoptimalkan penegakkan hukum perdagangan barang impor ilegal yang terjadi di wilayah hukum Polres Pelabuhan Tanjung Perak yaitu dengan upaya preemtif, upaya preventif dan upaya represif. Upaya preemtif terkait dengan melakukan sosialisasi terhadap importir dan masyarakat. Upaya preventif terkait dengan mendirikan posko-posko penjagaan di sekitar Pelabuhan, mendatangi tempat penyimpanan barang impor, mendatangi distributor maupun pasar-pasar untuk memberikan penjelasan terkait barang ilegal, melakukan sosialisasi terhadap importir serta menyamakan visi dan misi antar instansi dalam menangani kasus barang ilegal. Serta upaya represif yaitu mengumpulkan barang bukti, memanggil saksi-saksi dan dilakukan pemeriksaan melakukan penangkapan dan penahanan terhadap pelaku yang melakukan barang impor ilegal, menggeledah dan menyita barang bukti dan dilakukan proses sidik hingga dilimpahkan ke JPU.

\section{Bibliography}

Arief, Barda Nawawi. Kebijakan Hukum Pidana.Citra Aditya Bakti, Bandung, 2002, h. 11. Benny, Jimmy. Ekspor dan Impor Pengaruhnya Terhadap Posisi Cadangan Devisa di Indonesia.

Jurnal EMBA Vol. 1 No. 4 Desember, 2013. 
Eriyanto, Donny, Penyelundupan Lebih Berbahaya daripada Tsunami, Warta Bea Cukai. Edisi 370 September 2005

Haryono, Aan. Arus Ekspor dan Impor Meningkat di Pelabuhan Tanjung Perak. https://ekbis.sindonews.com/read/1219331/34/arus-ekspor-dan-impormeningkat-di- pelabuhan-tanjung-perak-1499676140. Diakses 7 April 2018.

Oktaviani, Rina. Laporan Akhir Pengkajian Hukum Tentang Penegakkan Hukum Pemberantasan

Mafia Impor Pangan. Kementerian Hukum dan Hak Asasi Manusia RI, Jakarta, 2015. 